\title{
Effects of Tenascin C on the Integrity of Extracellular Matrix and Skin Aging
}

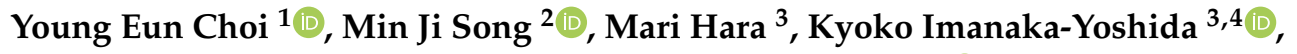 \\ Dong Hun Lee ${ }^{2,5}$, Jin Ho Chung ${ }^{2,5}$ and Seung-Taek Lee ${ }^{1, * \mathbb{D}}$ \\ 1 Department of Biochemistry, College of Life Science and Biotechnology, Yonsei University, \\ Seoul 03722, Korea; choii03271452@gmail.com \\ 2 Department of Dermatology, Seoul National University College of Medicine, Seoul 03080, Korea; \\ minjisong@snu.ac.kr (M.J.S.); ivymed27@snu.ac.kr (D.H.L.); jhchung@snu.ac.kr (J.H.C.) \\ 3 Department of Pathology and Matrix Biology, Mie University Graduate School of Medicine, \\ Tsu 514-8507, Japan; marihara@doc.medic.mie-u.ac.jp (M.H.); imanaka@doc.medic.mie-u.ac.jp (K.I.-Y.) \\ 4 Mie University Research Center for Matrix Biology, Tsu 514-8507, Japan \\ 5 Institute of Human-Environment Interface Biology, Medical Research Center, Seoul National University, \\ Seoul 03080, Korea \\ * Correspondence: stlee@yonsei.ac.kr; Tel.: +82-2-2123-2703
}

Received: 27 October 2020; Accepted: 16 November 2020; Published: 18 November 2020

\begin{abstract}
Tenascin C (TNC) is an element of the extracellular matrix (ECM) of various tissues, including the skin, and is involved in modulating ECM integrity and cell physiology. Although skin aging is apparently associated with changes in the ECM, little is known about the role of TNC in skin aging. In this study, we found that the Tnc mRNA level was significantly reduced in the skin tissues of aged mice compared with young mice, consistent with reduced TNC protein expression in aged human skin. TNC-large (TNC-L; 330-kDa) and -small (TNC-S; 240-kDa) polypeptides were observed in conditional media from primary dermal fibroblasts. Both recombinant TNC polypeptides, corresponding to TNC-L and TNC-S, increased the expression of type I collagen and reduced the expression of matrix metalloproteinase- 1 in fibroblasts. Treatment of fibroblasts with a recombinant TNC polypeptide, corresponding to TNC-L, induced phosphorylation of SMAD2 and SMAD3. TNC increased the level of transforming growth factor- $\beta 1$ (TGF- $\beta 1$ ) mRNA and upregulated the expression of type I collagen by activating the TGF- $\beta$ signaling pathway. In addition, TNC also promoted the expression of type I collagen in fibroblasts embedded in a three-dimensional collagen matrix. Our findings suggest that TNC contributes to the integrity of ECM in young skin and to prevention of skin aging.
\end{abstract}

Keywords: aging; collagen; extracellular matrix; fibroblast; skin; tenascin C; TGF- $\beta$

\section{Introduction}

Tenascin C (TNC) is a multimodular extracellular matrix (ECM) protein with multiple molecular forms that are generated by alternative splicing and post-translational modifications [1]. TNC contains an assembly domain essential for the formation of hexamers, epidermal growth factor (EGF)-like repeats, fibronectin type III-like repeats, and a C-terminal fibrinogen-like globular domain.

TNC is mainly expressed in distinct spatial and temporal patterns during embryonic development. TNC is weakly expressed in quiescent adult tissues but is strongly expressed under various pathological conditions such as tissue injury, wound healing, inflammation, and tumorigenesis [2-6].

Although TNC is not an obligatory structural element of the ECM, it binds to structural proteins and cell surface receptors such as the EGF receptor and integrins in the ECM [7-10]. Binding of 
TNC to these receptors activates their downstream pathways and affects cell proliferation, adhesion, and migration, depending on cell types and environments [11-15].

TNC is known to upregulate the expression of type I collagen in foreskin fibroblasts and hepatic stellate cells $[16,17]$. The expression of TNC is elevated in collagen diseases [16] that are characterized by inflammation, autoimmune attack, and vascular damage and often leads to fibrosis [18]. Patients with increased TNC levels show a higher incidence of diffuse cutaneous systemic sclerosis, severe thickened skin, and probability of pulmonary fibrosis compared to those with normal levels.

Transforming growth factor- $\beta$ (TGF- $\beta$ ) upregulates collagens and downregulates matrix metalloproteinases (MMPs), the major enzymes involved in degrading collagens and ECM components, and also contributes to the prevention of collagen loss in aged human skin [19]. TNC deficiency attenuates TGF- $\beta$-mediated fibrosis following immune-mediated chronic hepatitis [20] or acute lung injury [21]. TNC induces activation of hematopoietic stem cells mediated by TGF- $\beta 1$ and $\alpha 9 \beta 1$ integrin, thereby elevating type 1 collagen production and promoting cell migration [17]. TNC also activates the TGF- $\beta$ signaling pathway and induces the expression of type I collagen, at least in fibrotic lesions.

Previous studies suggest that TNC is implicated in collagen biosynthesis and is relevant to TGF- $\beta$ signaling in fibroblasts. However, the role of TNC in normal skin, particularly during aging, has not been studied. In the present study, we investigated the expression of TNC in skin tissues from young and aged mice and humans by reverse transcription-polymerase chain reaction (RT-PCR) and histological analysis. The major forms of TNC that are expressed in human primary dermal fibroblasts were also analyzed. Next, the major forms of human TNC were ectopically expressed, and the effect of recombinant TNC polypeptides on the secretion of type I collagen and MMP-1 in foreskin fibroblasts was analyzed. We then analyzed the molecular mechanism of TNC-induced upregulation of type I collagen. In addition, the effect of TNC on the synthesis of type I collagen was validated in fibroblasts cultured in a three-dimensional (3D) collagen matrix. Based on our findings, we suggest that TNC is an important molecule that maintains the ECM integrity and prevents and attenuates skin aging.

\section{Results}

\subsection{Expression of TNC is Downregulated during Intrinsic Skin Aging in Mouse and Human Skin Tissues}

To analyze the changes in Tnc mRNA level in mouse skin tissues during aging, Tnc mRNA levels in the skin tissues of young ( 3 months old) and aged ( 24 months old) mice were determined by RT-PCR. Tnc mRNA levels showed a significant decrease in the skin tissues of aged mice compared with young mice (Figure 1A). To examine the aging-associated changes in TNC level in human skin, immunohistochemical (IHC) and immunofluorescence (IF) analyses were performed in the sun-protected buttock skin tissues of young (in their 30s) and elderly (in their 70s) females. IHC staining of young skin tissues revealed that TNC signals were present in the dermis as well as the epidermis, particularly in the basal layer (Figure 1B). However, TNC staining was barely detectable in aged skin tissues (Figure 1B). The pattern of TNC staining by IF analysis was consistent with that by IHC analysis. In addition, more TNC-positive cells and higher TNC signals were evident in the dermis of young skin tissues than in the dermis of elderly skin tissues (Figure 1C).

\subsection{TNC Upregulates Type I Collagen Expression and Downregulates MMP-1 Expression in Fibroblasts}

The size of the TNC monomers varies due to alternative splicing [1]. When TNC polypeptides secreted by two independent lines of human dermal fibroblasts and one foreskin fibroblast line were analyzed by western blotting, two major TNC isoforms ( $\mathrm{L}$ and S) were detected. The expression of the larger isoform of TNC (TNC-L) was higher than that of the smaller isoform (TNC-S) in the human fibroblasts (Figure 2A). 


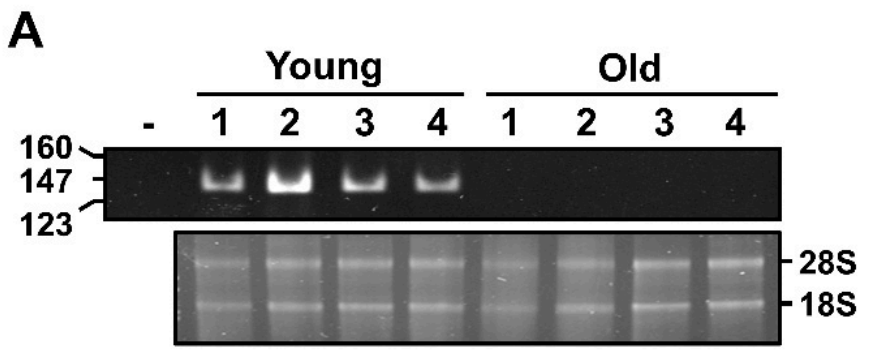

B

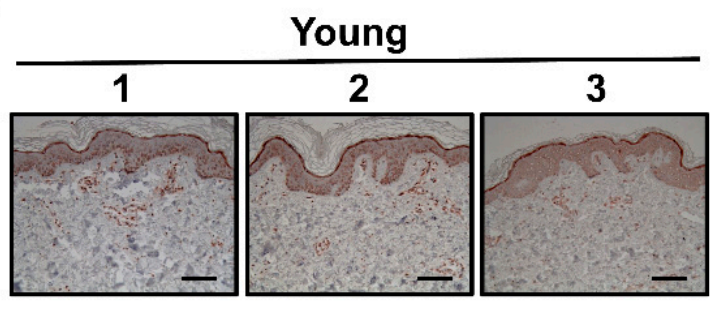

C

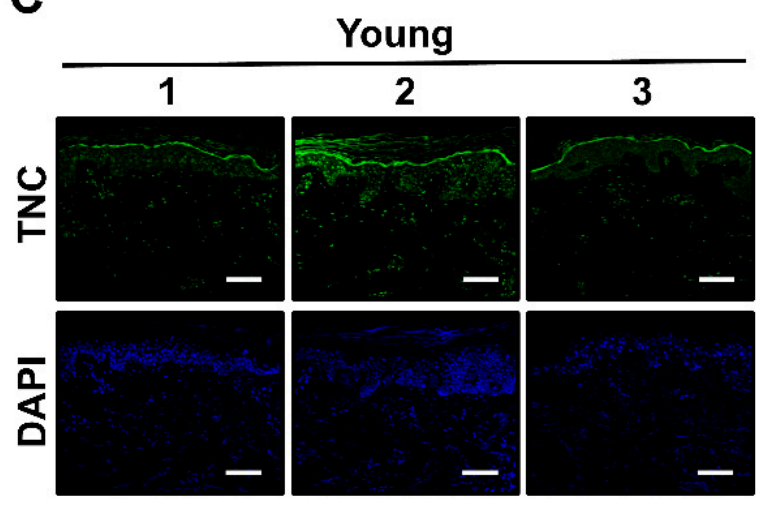

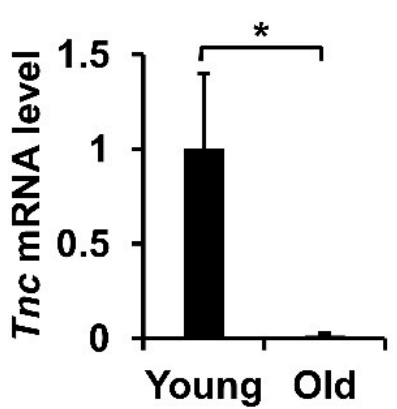
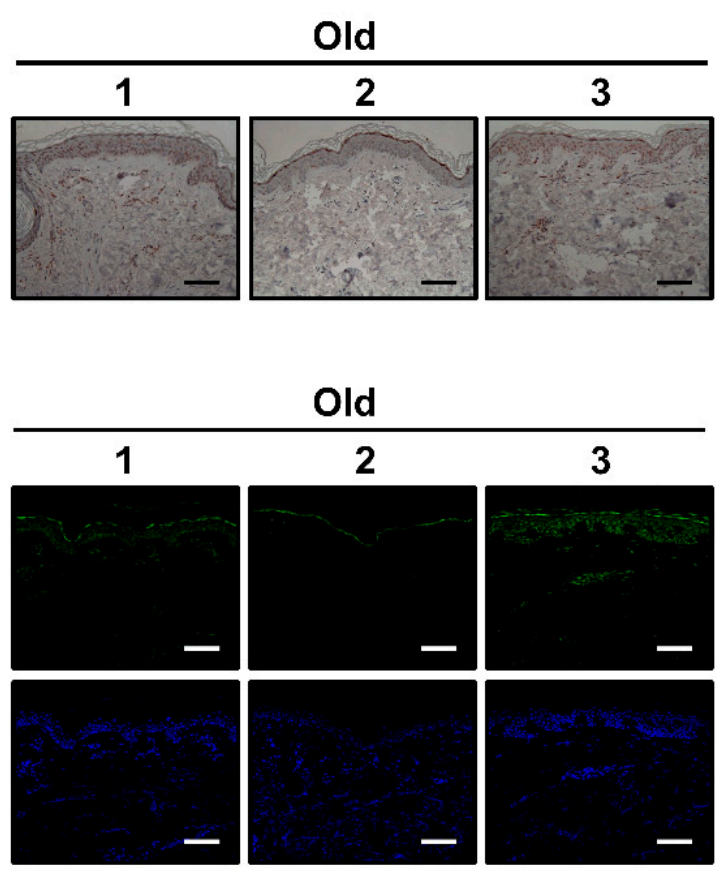

Figure 1. Analysis of tenascin C (TNC) expression in skin tissues from young and old mice and humans. (A) Tnc mRNA level was analyzed in mouse skin tissues by reverse transcription-polymerase chain reaction (RT-PCR). The panel on the right shows a graphical presentation of Tnc mRNA levels in mouse skin tissues quantified using multi-gauge densitometry software. Tnc mRNA level relative to that in skin tissues of young mice $(n=4)$ is shown as mean \pm SD. ${ }^{*} p<0.05$. -: no template as a negative control. (B,C) Immunohistochemical (IHC) (B) and immunofluorescence (IF) (C) analyses of TNC protein level in skin tissues from young and elderly human subjects. Sections of skin tissues were incubated with TNC antibody. For IHC, the specimens were stained with horseradish peroxidase-conjugated secondary antibody and 3-amino-9-ethylcarbazole and counterstained with hematoxylin. For IF, the specimens were incubated with secondary antibody conjugated with Alexa Flour 488 (green) and counterstained with $4^{\prime}$,6-diamidino-2-phenylindole (DAPI) (blue). Magnification, $\times 200$. Bar $=100 \mu \mathrm{m}$.

It has been reported that TNC isoforms secreted from dermal fibroblasts are similar in apparent molecular weights (MWs) to TNC isoforms consisting of 2201 amino acid residues (TNC-2201) and 1564 residues (TNC-1564) [22,23]. Thus, we directly compared the size of TNC isoforms secreted from fibroblasts with recombinant TNC-2201 and TNC-1564 isoforms ectopically expressed in COS-1 cells. We found that the apparent MWs of TNC-L and TNC-S expressed in fibroblasts are identical to those of recombinant TNC-2201 and TNC-1564, respectively (Figure 2B).

We next analyzed whether TNC could induce changes in the expression of type I collagen and MMP-1 in foreskin fibroblasts. Cells were treated with recombinant human TNC-2201 and TNC-1564 polypeptides as well as TGF- $\beta 1$ (as a positive control). Both recombinant TNC polypeptides as well as TGF- $\beta 1$ caused a significant increase in type I collagen and a significant decrease in MMP-1 at the 
protein level (Figure 2C). The two TNC isoforms, however, showed no difference in the increase of type I collagen level and the decrease of MMP-1 level (Figure 2C). Therefore, a recombinant TNC-2201 polypeptide was used for further analysis of TNC.

A

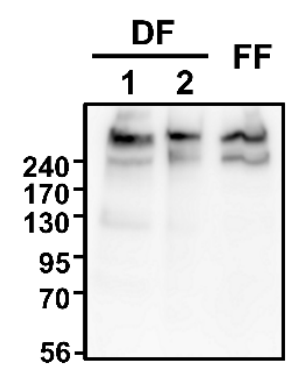

B

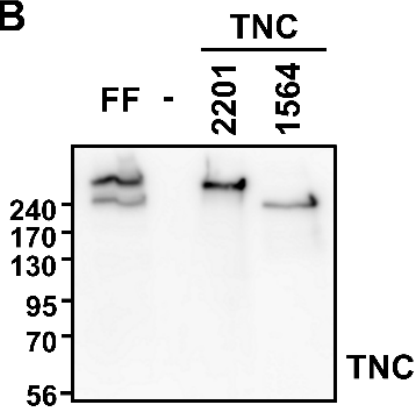

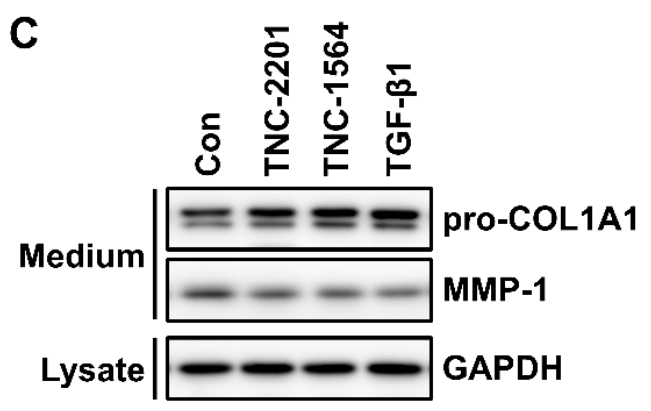
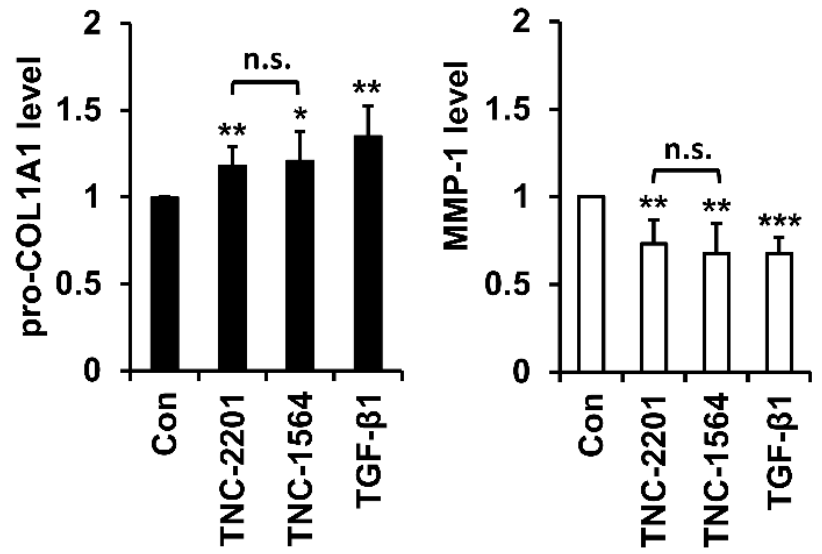

Figure 2. Detection of expression of TNC isoforms in fibroblasts, ectopic expression of recombinant TNC isoforms, and their effects on the secretion of type I collagen and matrix metalloproteinase-1 (MMP-1) in fibroblasts. (A) TNC levels were analyzed in conditioned media from two independent lines of human dermal fibroblasts (DF) and one foreskin fibroblast (FF) line by western blotting with an antibody against TNC. (B) Constructs expressing the large (TNC-2201) and small (TNC-1564) TNC isoforms were transfected into COS-1 cells, and the purified TNC proteins were analyzed by western blotting with TNC antibody. -: vector control. (C) Human foreskin fibroblasts were incubated with serum-free Dulbecco's modified Eagle's medium (DMEM) in the absence (Con) or presence of TNC $(2 \mu \mathrm{g} / \mathrm{mL})$ or transforming growth factor- $\beta 1$ (TGF- $\beta 1)(3 \mathrm{ng} / \mathrm{mL})$ for $24 \mathrm{~h}$. Levels of type I collagen and MMP-1 were evaluated in conditioned media and that of GAPDH in cell lysates by western blot analysis using antibodies against pro-COL1A1, MMP-1, and GAPDH. Graphs show the relative protein levels of pro-COL1A1 and MMP-1. Each value represents the mean \pm SD of six independent experiments. ${ }^{*} p<0.05,{ }^{* *} p<0.01,{ }^{* * *} p<0.001$ vs. Con. n.s.: not significant.

The mRNA levels of COL1A1, COL1A2, and MMP-1 with or without TNC treatment were analyzed in foreskin fibroblasts by conventional and quantitative RT-PCR. As expected, COL1A1 and 
COL1A2 mRNA levels were significantly upregulated following treatment with TNC as well as TGF- $\beta 1$ (Figure 3). However, MMP-1 mRNA level was decreased following TNC treatment, although the difference was not statistically significant (Figure 3).
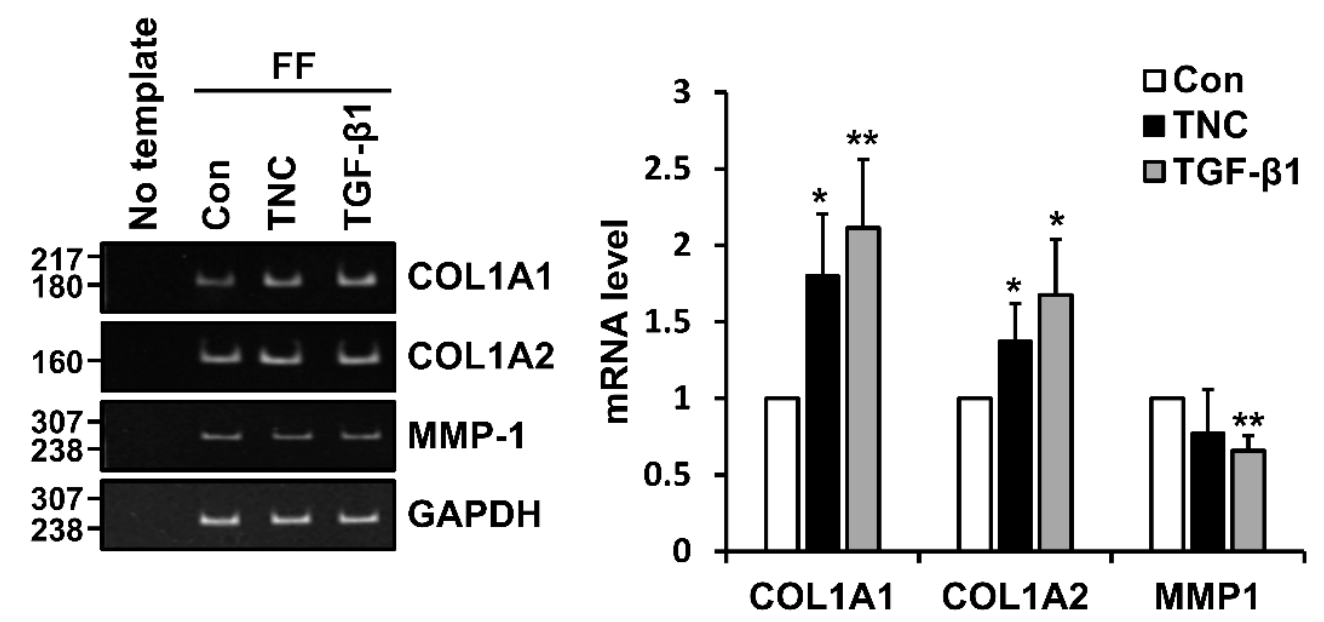

Figure 3. Effect of TNC on the levels of type I collagen and MMP-1 mRNAs in human fibroblasts. Serum-starved human foreskin fibroblasts (FF) were incubated without (Con) or with TNC $(2 \mu \mathrm{g} / \mathrm{mL})$ or TGF- $\beta 1$ (3 ng/mL) for $12 \mathrm{~h}$. Levels of COL1A1, COL1A2, and MMP-1 mRNAs were evaluated by conventional (left) and quantitative (right) RT-PCR analyses. Each value represents the mean $\pm \mathrm{SD}$ of five independent experiments. ${ }^{*} p<0.05,{ }^{* *} p<0.01$ vs. Con.

\subsection{TNC Activates Receptor-Regulated SMADs (R-SMADs) and TGF- $\beta$ Receptors in Fibroblasts}

To elucidate whether the TNC-mediated induction of type I collagen expression involves TGF- $\beta$ signaling pathway, we analyzed the activation of representative R-SMADs, SMAD2, and SMAD3 in foreskin fibroblasts following TNC treatment. Treatment with TNC $(2 \mu \mathrm{g} / \mathrm{mL})$ as well as TGF- $\beta 1$ $(3 \mathrm{ng} / \mathrm{mL}$ ) increased the phosphorylation of SMAD2 and SMAD3 (Figure 4A). Next, the effect of SB431542, an inhibitor of TGF- $\beta$ receptor type I, was examined on TNC-induced SMAD2 activation in foreskin fibroblasts. Treatment with SB431542 abolished SMAD2 phosphorylation induced by TNC and severely impaired TGF- $\beta 1$-induced phosphorylation (Figure 4B). In addition, SB431542 inhibited TNC-induced type I collagen secretion, whereas it restored TNC-mediated suppression of MMP-1 secretion (Figure 4C). These results demonstrate that TNC induces type I collagen expression via activation of TGF- $\beta$ receptors and R-SMADs.

We further performed the time-course analysis of SMAD2 phosphorylation following treatment with TNC or TGF- $\beta 1$ for up to $810 \mathrm{~min}$ in foreskin fibroblasts. Phosphorylation of SMAD2 peaked $90 \mathrm{~min}$ after TNC treatment, but it peaked $30 \mathrm{~min}$ after TGF- $\beta 1$ treatment (Figure 5). Based on these results, we speculate that TNC activates TGF- $\beta$ receptors in a different way than TGF- $\beta 1$.

\subsection{TNC Induces TGF- $\beta$ Family Members in Fibroblasts}

Integrins are known to induce TGF- $\beta$ expression or activate latent forms of TGF- $\beta$ [24]. To determine whether integrins are involved in TNC-mediated SMAD activation, the activation of integrins was blocked by treatment with RGD peptide or TC-I15. However, RGD peptide and TC-I15 did not affect TNC-induced SMAD2 activation in foreskin fibroblasts (Figure 6A).

To investigate whether TNC induces the biosynthesis of TGF- $\beta$ members, foreskin fibroblasts were treated with cycloheximide, a translation inhibitor, along with TNC or TGF- $\beta 1$. While cycloheximide did not decrease TGF- $\beta 1$-induced SMAD2 phosphorylation, it significantly reduced TNC-induced SMAD2 phosphorylation (Figure $6 \mathrm{~B}$ ), suggesting that TNC-induced activation of TGF- $\beta$ receptors involves the biosynthesis of a signaling molecule. 
We next analyzed the TNC-induced modulation of expression of TGF- $\beta$ family members in foreskin fibroblasts. Conventional and quantitative RT-PCR analyses showed that TNC increased the level of TGF- $\beta 1$ mRNA (Figure $6 C$ ). Although the mRNA levels of TGF- $\beta 2$ and TGF- $\beta 3$ were very low, TNC also increased their mRNA levels (Figure 6C). In addition, treatment with a TGF- $\beta$ neutralizing antibody $(3 \mu \mathrm{g} / \mathrm{mL})$ inhibited both TNC-induced SMAD2 phosphorylation (Figure 6D). These results demonstrate that TNC-induced SMAD2 activation involves the induction of TGF- $\beta 1$.
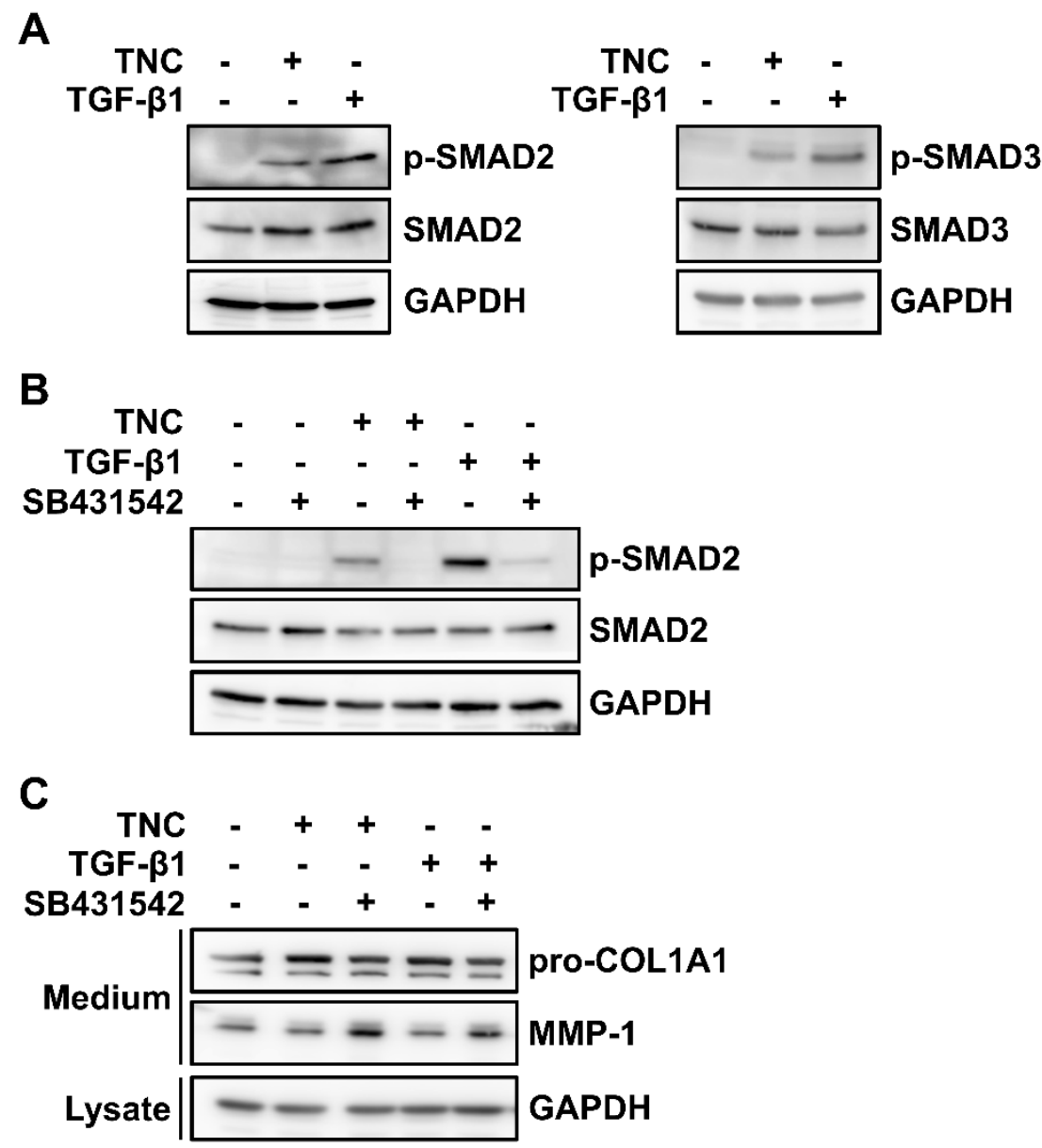

Figure 4. Analysis of receptor-regulated SMAD activation by TNC in fibroblasts. (A) Subconfluent human foreskin fibroblasts were starved for $12 \mathrm{~h}$ and then incubated with TNC $(2 \mu \mathrm{g} / \mathrm{mL})$ or TGF- $\beta 1$ ( $3 \mathrm{ng} / \mathrm{mL}$ ) for $90 \mathrm{~min}$. Cell lysates were analyzed by western blotting using antibodies against phospho-SMAD2 (p-SMAD2), SMAD2, phospho-SMAD3 (p-SMAD3), SMAD3, and GAPDH. (B) Serum-starved foreskin fibroblasts were preincubated with SB431542 $(10 \mu \mathrm{M})$ for $10 \mathrm{~min}$ and then stimulated with TNC $(2 \mu \mathrm{g} / \mathrm{mL})$ or TGF- $\beta 1(3 \mathrm{ng} / \mathrm{mL})$ for $90 \mathrm{~min}$. Cell lysates were analyzed by western blotting with antibodies against p-SMAD2, SMAD2, and GAPDH. (C) Serum-starved foreskin fibroblasts were stimulated with TNC $(2 \mu \mathrm{g} / \mathrm{mL})$ or TGF- $\beta 1(3 \mathrm{ng} / \mathrm{mL})$ in the presence of SB431542 $(10 \mu \mathrm{M})$ for $24 \mathrm{~h}$. Levels of type I collagen and MMP-1 in conditioned media and GAPDH in cell lysates were evaluated by western blot analysis using antibodies against pro-COL1A1, MMP-1, and GAPDH. 

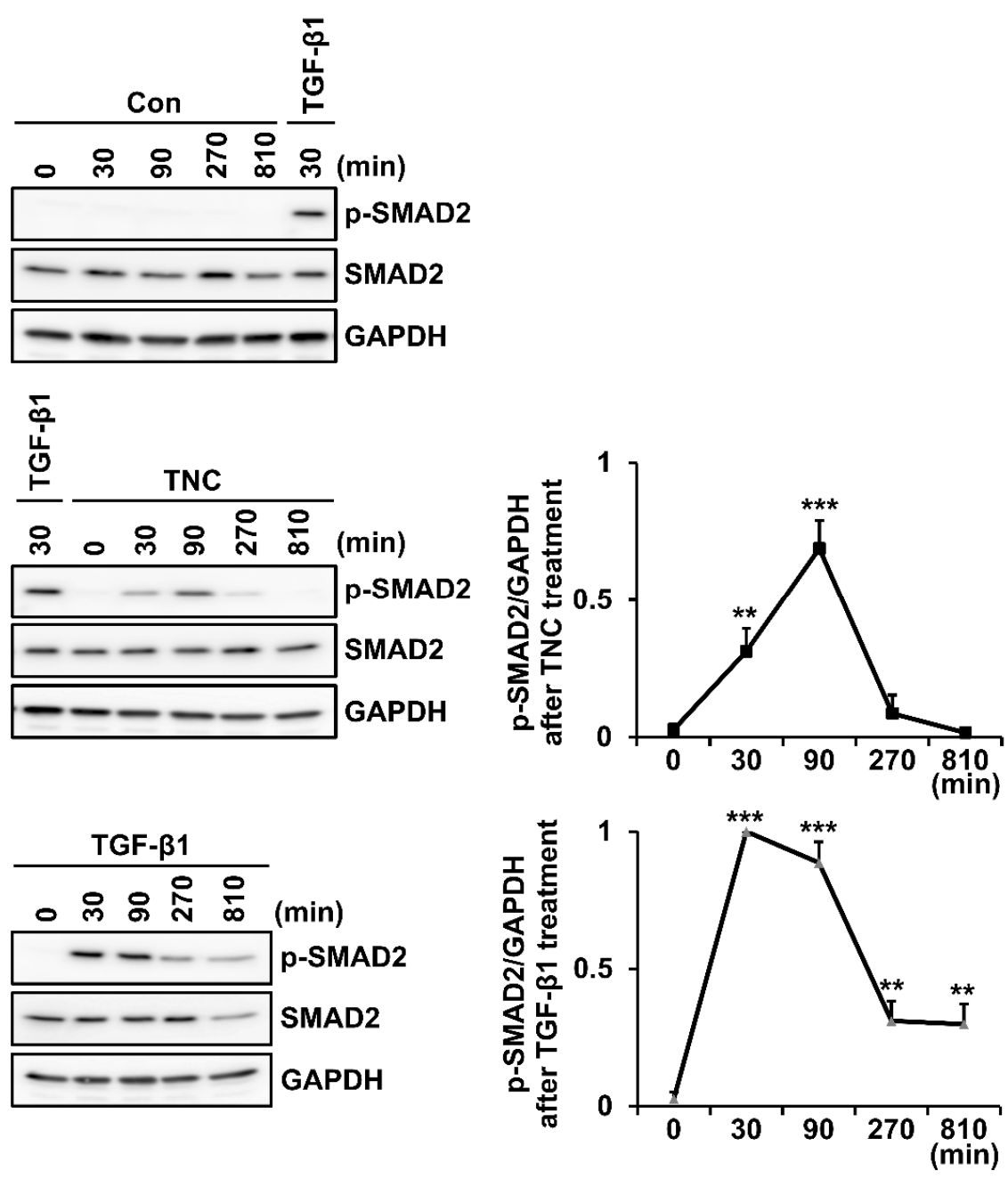

Figure 5. Time course effect of TNC on SMAD2 phosphorylation in fibroblasts. Serum-starved human foreskin fibroblasts were treated with vehicle (Con), TNC $(2 \mu \mathrm{g} / \mathrm{mL})$, or TGF- $\beta 1$ ( $3 \mathrm{ng} / \mathrm{mL})$. After incubation for the indicated durations $(0,30,90,270$, and $810 \mathrm{~min})$, cell lysates were analyzed by western blotting using antibodies against phospho-SMAD2 (p-SAMD2), SMAD2, and GAPDH. Relative intensity of p-SMAD2/GAPDH in samples treated with TNC or TGF- $\beta 1$, normalized to a sample treated with TGF- $\beta 1$ for $30 \mathrm{~min}$, are shown in graphs. Each value represents the mean \pm SD of four independent experiments. ${ }^{* *} p<0.01,{ }^{* * *} p<0.001$ vs. $0 \mathrm{~min}$.

\subsection{TNC Increases the Biosynthesis of Type I Collagen during 3D Culture of Fibroblasts}

To examine whether TNC affects ECM integrity in young mice, the skin tissues of young (6 weeks old) Tnc knockout (KO) and wild-type (WT) mice $(n=5)$ were stained with Masson's trichrome, and the dermal thickness and collagen density in the dermis were measured. Both dermal thickness and collagen intensity were reduced in skin tissues from Tnc KO mice compared with WT mice, albeit not statistically significant (Supplementary Figure S1).

To analyze the effect of TNC on ECM integrity under in vivo-mimicking conditions, we investigated whether TNC affects the production of type I collagen in the 3D cultures of foreskin fibroblasts. Interestingly, TNC significantly increased the amount of newly synthesized type I collagen under 3D culture condition (Figure 7). These data suggest that TNC plays an important role in maintaining the ECM integrity of connective tissues such as skin. 
A
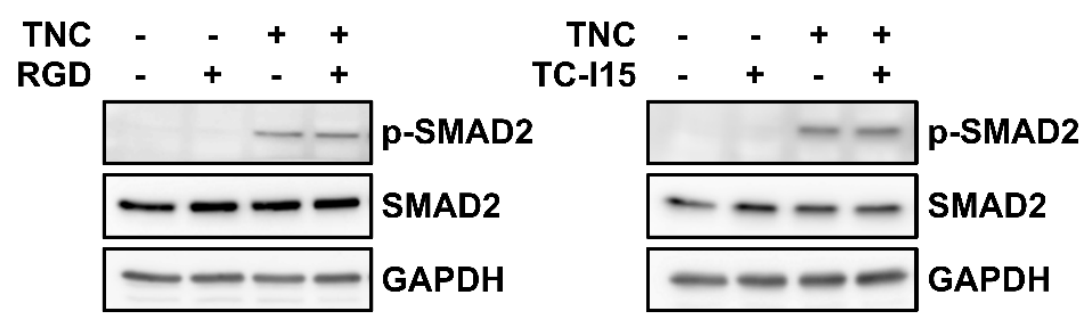

B

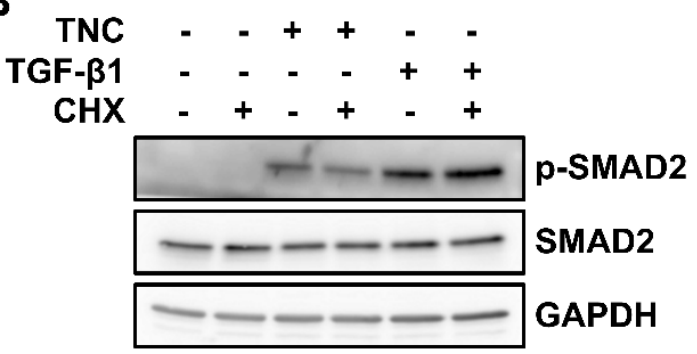

C
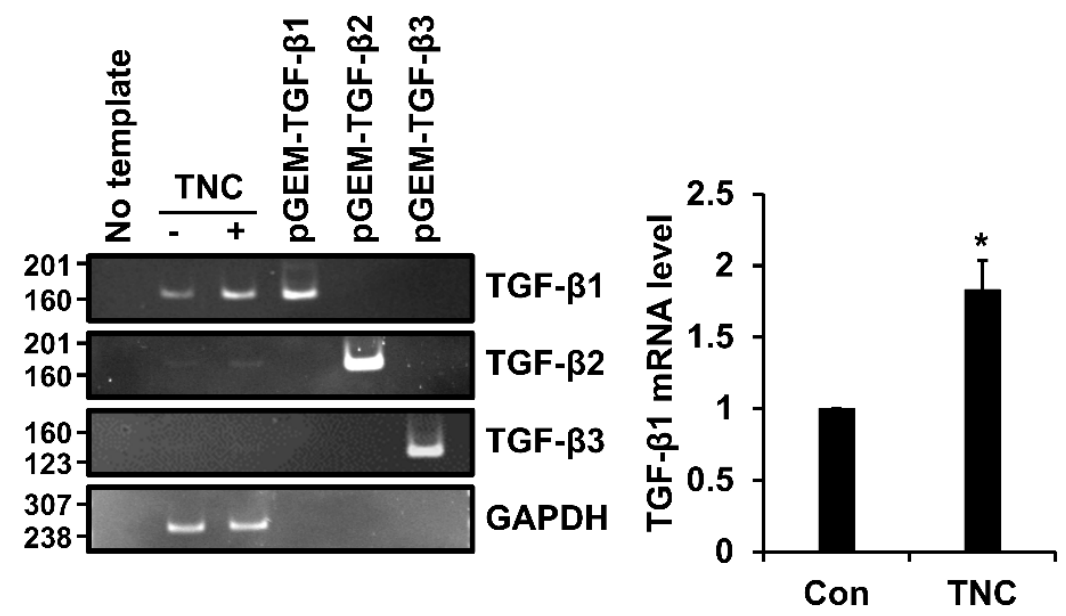

D

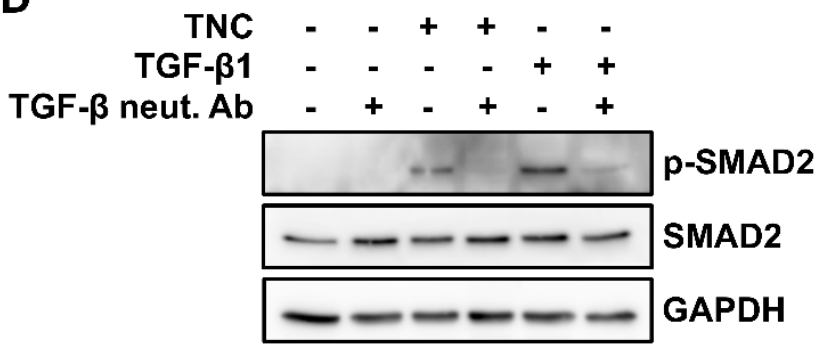

Figure 6. Analysis of the involvement of TGF- $\beta 1$ in TNC-induced SMAD2 activation in fibroblasts. (A,B) Subconfluent human foreskin fibroblasts were starved for $12 \mathrm{~h}$ and then incubated with RGD peptide $(100 \mu \mathrm{g} / \mathrm{mL})$ or TC-I15 $(2 \mu \mathrm{M})(\mathbf{A})$ or cycloheximide $(\mathrm{CHX} ; 10 \mu \mathrm{g} / \mathrm{mL})(\mathbf{B})$ for $10 \mathrm{~min}$ and then stimulated with TNC $(2 \mu \mathrm{g} / \mathrm{mL})$ or TGF- $\beta 1(3 \mathrm{ng} / \mathrm{mL})$ for $90 \mathrm{~min}$. Cell lysates were analyzed by western blotting with antibodies against p-SMAD2, SMAD2, and GAPDH. (C) Subconfluent human foreskin fibroblasts were incubated in the absence or presence of TNC $(2 \mu \mathrm{g} / \mathrm{mL})$ for $12 \mathrm{~h}$. TGF- $\beta 1$, TGF- $\beta 2$, and TGF- $\beta 3$ mRNA levels were evaluated by conventional RT-PCR analysis using $1 \mathrm{ng}$ of pGEM-TGF- $\beta 1,2$, and 3 as controls and further by quantitative RT-PCR analysis. Graph on the right shows the relative level of TGF- $\beta 1$ mRNA normalized to GAPDH mRNA level. Each value represents the mean \pm SD of three independent experiments. ${ }^{*} p<0.05$ vs. Con. (D) Subconfluent human foreskin fibroblasts were incubated with TGF- $\beta$ neutralizing antibody (TGF- $\beta$ neut. Ab; $3 \mu \mathrm{g} / \mathrm{mL}$ ) and analyzed for western blotting, as described in $(\mathbf{A}, \mathbf{B})$. 

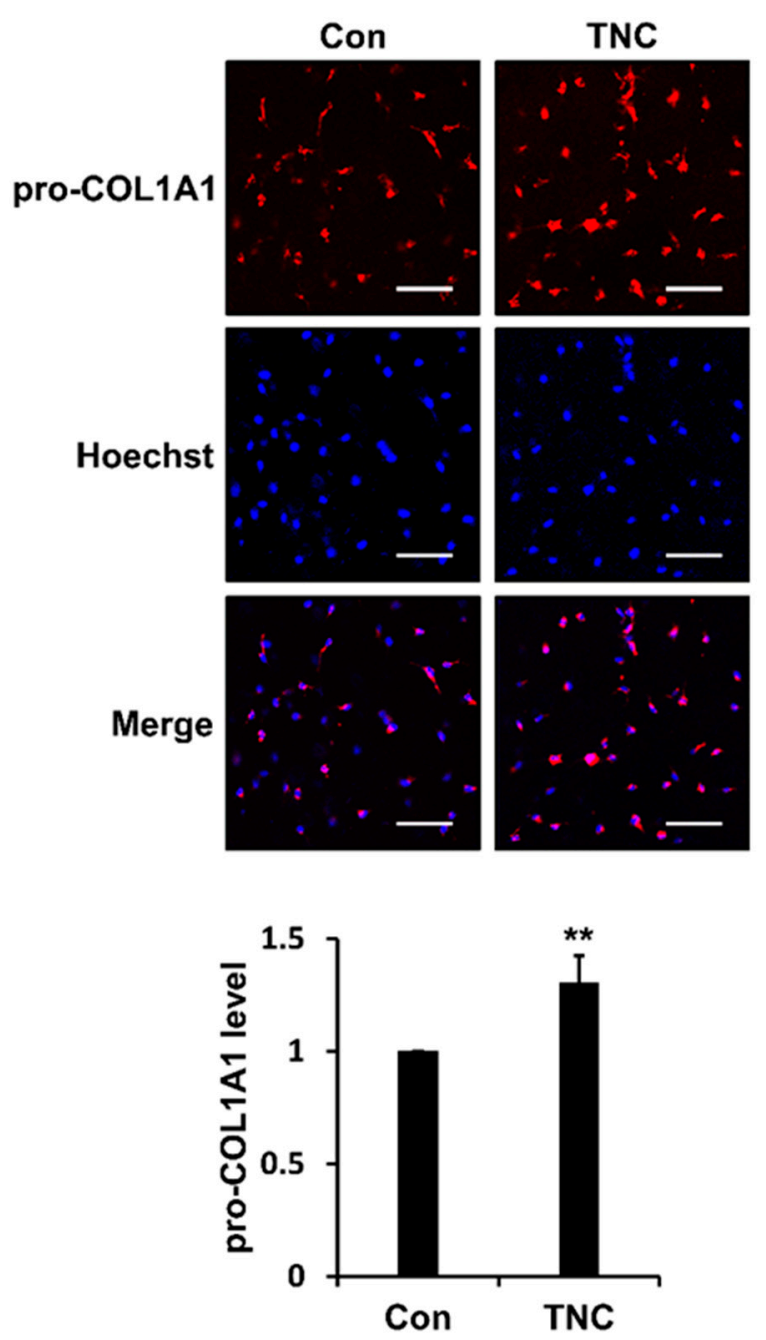

Figure 7. Effect of TNC on secretion of type I collagen during three-dimensional (3D) culture of fibroblasts. Foreskin fibroblasts embedded within a 3D type I collagen matrix without (Con) or with TNC $(2 \mu \mathrm{g} / \mathrm{mL})$ were incubated in serum-free DMEM for $24 \mathrm{~h}$. The 3D matrix containing fibroblasts was stained with pro-COL1A1 primary antibody and Rhodamine Red-X secondary antibody, and with Hoechst 33258 for nuclear staining. Cells were analyzed by confocal fluorescence microscopy $(\times 200)$. Relative pro-COL1A1 staining intensity normalized to nuclear staining intensity is shown in a graph. Each value represents the mean \pm SD of three independent experiments. ${ }^{* *} p<0.01$ vs. Con. Bar $=100 \mu \mathrm{m}$.

\section{Discussion}

TNC is expressed at relatively low levels in normal adult human skin. However, TNC expression is significantly elevated in the dermal compartment during wound healing and in skin tumors $[25,26]$. We found that the level of Tnc mRNA was downregulated in the dorsal skin tissue of aged mice compared with young mice. In addition, IHC staining showed that TNC levels in sun-protected skin tissues of elderly females were markedly lower than those of young females. Moreover, the expression of type I procollagen mRNA and protein in sun-protected skin tissues gradually decreased during the intrinsic aging process [27]. Based on these results, we hypothesize that TNC is an important molecule involved in intrinsic skin aging by modulating ECM integrity.

Although basal keratinocytes are the major source of TNC in the early phase of wound healing, cultured dermal fibroblasts express more TNC than cultured keratinocytes [26,28]. Northern blot analysis revealed that TNC is expressed in two forms in the human skin [26]. The larger TNC transcript, with 7500 nucleotides, is more abundant than the smaller TNC transcript, with 5800 nucleotides, in skin 
tissues and fibroblasts [26]. Two TNC polypeptides of 320- and 220-kDa were detected in dermal fibroblasts [22]. Recombinant TNC polypeptides secreted from BHK cells were detected as 320- and 220-kDa bands corresponding to the 2201- and 1564-amino acid residue isoforms, respectively [23]. We also detected two main TNC variants, the more abundant 330-kDa TNC-L and the less abundant 240-kDa TNC-S forms, in conditioned media from human dermal fibroblasts by western blotting. Based on our results that TNC-L and TNC-S forms detected in dermal fibroblasts are the same in apparent MW as recombinant TNC-2201 and TNC-1564, TNC-L and TNC-S likely correspond to TNC-2201 and TNC -1564, respectively.

Different TNC isoforms can activate different cell signaling by modulating interactions with ECM components and cell surface receptors. The larger MW isoforms of TNC are associated with the induction of cell proliferation and migration by interacting with fibronectin, annexin II, and syndecan-4 $[29,30]$. In contrast, the smaller MW isoforms bind to fibronectin with high affinity and promote cell adhesion through the formation of focal adhesions [31-33]. When we treated foreskin fibroblasts with recombinant human TNC-2201 and TNC-1564 forms, both increased expression of type I collagen and reduced expression of MMP-1 without a significant discrepancy.

Although TNC is widely expressed in the embryo, Tnc-deficient mice develop normally and grow without any noticeable phenotype [34,35]. Later in life, some defects such as reduced fibrosis and altered inflammatory responses have been reported in these mice [21,36-38]. TNC deficiency reduced inflammation, TGF- $\beta$ expression, and fibrosis in a murine chronic hepatitis model [20]. TNC deficiency lowered SMAD-mediated fibrosis in a murine lung injury model [21] and bleomycin-induced skin fibrosis model [16]. Similarly, we found that TNC activates phosphorylation of SMAD2/3 in foreskin fibroblasts. Interestingly, the SMAD2 phosphorylation peaked after TNC treatment with a delay than after TGF- $\beta 1$ treatment, namely $90 \mathrm{~min}$ and $30 \mathrm{~min}$ after the treatment, respectively. Delayed stimulation of SMAD2/3 by TNC compared with TGF- $\beta$ was recently reported in mammary fibroblasts [15]. These results suggest that TNC and TGF- $\beta 1$ activate SMAD2 and induce type I collagen expression through different mechanisms.

Integrins activate latent TGF- $\beta$ and the TGF- $\beta$ signaling pathway [24]. For example, integrin $\alpha v \beta 6$ activates latent TGF- $\beta 1$ by binding to the RGD motif of latency-associated peptide $\beta 1$ and causes actin-dependent physical deformation of the TGF- $\beta$ large latent complex, exposing TGF- $\beta$ to TGF- $\beta$ receptors on adjacent cells [39]. A recent study reported that TNC-induced SMAD2/3 phosphorylation in an integrin $\alpha v \beta 1$-dependent manner in mammary fibroblasts [15]. In addition, integrins are known to induce TGF- $\beta$ and collagen expression through the activation of FAK and p42/p44 MAPK in mesangial cells [40]. However, we observed that the integrin inhibitors, RGD peptide and TC-I15, did not affect TNC-induced SMAD activation in foreskin fibroblasts. Interestingly, we found that incubation with cycloheximide significantly reduced TNC-induced SMAD2 phosphorylation, whereas it did not affect TGF- $\beta 1$-induced SMAD2 phosphorylation. These results suggest that TNC-induced SMAD2 phosphorylation is caused by a newly synthesized signaling molecule. We found that TNC induced TGF- $\beta 1$ mRNA expression in foreskin fibroblasts and that treatment with a TGF- $\beta$ neutralizing antibody abolished TNC-induced SMAD2 activation. These results show that TNC induces type I collagen in foreskin fibroblasts at least in part by inducing TGF- $\beta 1$ and activating SMAD2/3 through the TGF- $\beta$ receptors.

We found that TNC suppressed MMP-1 via TGF- $\beta 1$ induction in foreskin fibroblasts, whereas it induced type I collagen. Consistent with our finding, TGF- $\beta$ signaling suppresses MMP-1 by binding to TGF- $\beta$ inhibitory elements found in promoters of some MMP genes in fibroblasts [41]. However, TNC was reported to induce MMP-1 expression via MEK1 activation in chondrosarcoma cells [42] and activate ERK, JNK, and p38 MAPK, and integrin $\beta 1$ and $\beta 3$ in airway smooth muscle cells [43]. We assume that modulation of MMP-1 by TNC is dependent on cell types and environments.

The skin is an organ that is most strongly influenced by external and internal factors and plays an important role in maintaining the body's homeostasis. As the skin ages, the skin becomes thinner and less elastic, and wrinkles appear. Compared to photoaging, which is strongly affected by UV 
and external factors, intrinsic aging is influenced by changes in gene expression and metabolic factors [44-46].

Altered TNC expression or function is associated with fibrosis in animal models [18]. For example, experimental acute lung injury, myocardial infarction, and liver and corneal injuries are associated with increased TNC accumulation and decreased resulting fibrosis in Tnc KO mice [20,21,47]. We also noted a decrease in dermal thickness and collagen intensity in skin tissues from young Tnc KO mice compared with young WT mice, although the decrease was not statistically significant. Such a small difference can be caused by a compensatory mechanism in young Tnc $\mathrm{KO}$ mice. In fact, the expression of tenascin W, which can complement with TNC, was increased in dermal fibroblasts from Tnc KO mice [48]. To overcome this limitation, we demonstrated that TNC increased type I collagen expression using the 3D culture of fibroblasts. These results provide compelling evidence that TNC strengthens ECM integrity in 3D matrix environments such as the skin.

\section{Materials and Methods}

\subsection{Reagents and Antibodies}

Recombinant human TGF- $\beta 1$ was purchased from PeproTech (Princeton, NJ, USA). SB431542 was purchased from Selleckchem (Houston, TX, USA). RGD peptide was purchased from Santa Cruz Biotechnology (Dallas, TX, USA). TGF- $\beta$ neutralizing antibody was purchased from R\&D Systems (Minneapolis, MN, USA). Anti-TNC antibodies for IHC staining and western blot analysis were purchased from Santa Cruz Biotechnology and Abcam (Cambridge, UK), respectively. Anti-GAPDH antibody was from AbClone (Seoul, Korea). Anti-SMAD2 (SMAD family member 2), anti-phospho-SMAD2, anti-SMAD3, and anti-phospho-SMAD3 antibodies were from Cell Signaling Technology (Danvers, MA, USA). Anti-pro-COL1A1 and anti-MMP-1 antibodies have been described previously [49]. Horseradish peroxidase (HRP)-conjugated goat anti-mouse IgG, goat anti-rabbit IgG, and rabbit anti-goat IgG antibodies were purchased from KOMA Biotech (Seoul, Korea). Rhodamine Red-X-conjugated goat anti-mouse IgG and Alexa Fluor 488-conjugated rabbit anti-goat IgG antibodies were purchased from Invitrogen (Carlsbad, CA, USA).

\subsection{Cell Culture}

Foreskin fibroblasts (Welskin, Seoul, Korea) and dermal fibroblasts [50] were grown in Dulbecco's modified Eagle's medium (DMEM; Gibco, Waltham, MA, USA) supplemented with $10 \%$ fetal bovine serum (FBS; Gibco). Monkey kidney-derived COS-1 cells were grown in DMEM supplemented with $5 \%$ FBS. All the cells were grown at $37^{\circ} \mathrm{C}$ under $5 \% \mathrm{CO}_{2}$ and $95 \%$ air.

\subsection{Acquisition of Mouse and Human Skin Tissues}

Dorsal skin tissues were obtained from young ( 3 months old) and old (24 months old) female albino hairless (Skh-1) mice (Orient Bio, Seoul, Korea). Punch biopsy specimens $(8 \mathrm{~mm})$ were obtained from the buttock skin of young (aged 32, 34, and 35 years) and older (aged 72, 74, and 77 years) females without current or prior skin diseases. The skin tissues were fixed in 10\% formalin for histological analysis, frozen in liquid nitrogen, and stored at $-70{ }^{\circ} \mathrm{C}$ for RNA analysis. All procedures involving mice and human subjects received prior approval from the Institutional Animal Care and Use Committee and the Institutional Review Board, respectively. All the human subjects provided written informed consent.

\subsection{RNA Isolation and RT-PCR Analysis}

Total RNA isolation, cDNA synthesis, and RT-PCR analysis were performed as previously described with minor modifications [51,52]. Total RNA was isolated from the mouse skin tissues and fibroblasts using TRIzol (Invitrogen). cDNAs were synthesized from $1 \mu \mathrm{g}$ of total RNA using oligo $(\mathrm{dT})_{15}$ primer and AMV RT system (Promega, Madison, WI, USA) according to the manufacturer's instructions. 
The amplification reaction was performed in a final volume of $10 \mu \mathrm{L}$, which consisted of $1 \mathrm{pM}$ of each of the $5^{\prime}$ and $3^{\prime}$ primers, $0.2 \mathrm{mM}$ dNTPs, $1 \times$ PCR buffer, 50 unit/mL Taq polymerase, and cDNAs synthesized from $0.1 \mu \mathrm{g}$ total RNA. PCR consisted of 21 to 30 cycles of the following steps: denaturation at $94{ }^{\circ} \mathrm{C}$ for $30 \mathrm{~s}$, annealing at the appropriate annealing temperature (Supplementary Table S1) for $60 \mathrm{~s}$, and extension at $72{ }^{\circ} \mathrm{C}$ for $20 \mathrm{~s}$. The PCR products were detected by electrophoresis on a $5 \%$ polyacrylamide gel and visualized by staining with ethidium bromide. The expression of target genes was normalized to that of GAPDH gene. Real-time PCR was performed at annealing temperatures described above, using a QuantiTect SYBR Green PCR kit (Qiagen, Hilden, Germany) and the QuantStudio 3 Real-Time PCR system (Applied Biosystems, Foster City, CA, USA).

\subsection{Histological Analysis}

Skin tissues fixed in $10 \%$ formalin were embedded in paraffin wax. The paraffin-embedded samples were sectioned into $4-\mu \mathrm{m}$ sections and mounted on silane-coated slides (Dako, Glostrup, Denmark). The mounted skin specimens were dewaxed in xylene substitutes, rehydrated with graded ethanol, and washed with distilled water. For IHC staining, the deparaffinized tissue sections were incubated with goat anti-TNC antibody (1:200) in a humidified chamber at $4{ }^{\circ} \mathrm{C}$ for $16 \mathrm{~h}$. After washing with phosphate-buffered saline (PBS), the sections were visualized using an LSAB kit (Dako), which incorporated a biotinylated secondary antibody and horseradish peroxide-streptavidine conjugate. 3-amino-9-ethylcarbazole was used as the chromogenic substrate, and the sections were counterstained with Mayer's hematoxylin. Control staining was performed with normal goat IgG antibody and showed no immunoreactivity (data not shown). For IF staining, the deparaffinized tissue sections were stained with goat anti-TNC antibody and Alexa Fluor 488-conjugated rabbit anti-goat IgG antibody for $1 \mathrm{~h}$ at $25^{\circ} \mathrm{C}$. Nuclei were counterstained with $4^{\prime}$,6-diamidino-2-phenylindole. For hematoxylin and eosin staining, deparaffinized tissue sections were incubated with absolute alcohol and washed with distilled water. Each tissue section was stained with Harris hematoxylin solution and differentiated in $1 \%$ acid alcohol. After bluing with $0.2 \%$ ammonia water for $1 \mathrm{~min}$, the sections were counterstained with eosin-phloxine solution and dehydrated with $95 \%$ alcohol. Finally, the tissue sections were mounted with a xylene-based mounting medium.

\subsection{Western Blot Analysis}

Conditioned media were collected from cultured cells and the cell debris was removed by centrifugation at $2000 \times g$ for $3 \mathrm{~min}$. Cells were washed with PBS twice and lysed with $1 \times$ sodium dodecyl sulfate (SDS) sample buffer for analysis of GAPDH or with radioimmunoprecipitation assay buffer $(50 \mathrm{mM}$ Tris- $\mathrm{HCl}, \mathrm{pH} 7.4,150 \mathrm{mM} \mathrm{NaCl}, 1 \% \mathrm{NP}-40,0.5 \%$ sodium deoxycholate, and $0.1 \%$ SDS) containing $1 \mathrm{mM} \mathrm{NaF}, 1 \mathrm{mM} \mathrm{NA}_{3} \mathrm{VO}_{4}$, and SIGMAFAST ${ }^{\mathrm{TM}}$ protease inhibitor tablet (Sigma-Aldrich, St. Louis, MO, USA) for analysis of signaling proteins. Protein samples were resuspended in $1 \times$ SDS sample buffer ( $50 \mathrm{mM}$ Tris- $\mathrm{HCl}, \mathrm{pH} 6.8,2 \%$ SDS, $0.1 \%$ bromophenol blue, and $10 \%$ glycerol) containing $100 \mathrm{mM} \beta$-mercaptoethanol, boiled for $2 \mathrm{~min}$, and then resolved by SDS-PAGE. Proteins in the gel were blotted onto a polyvinylidene difluoride membrane (Millipore, Billerica, MA, USA). The blot was incubated with primary and secondary antibodies. Immunoreactive signals were detected with Immobilon Western Chemiluminescent HRP Substrate (Millipore) and LAS-3000 (Fujifilm, Tokyo, Japan).

\subsection{Construction of TNC Expression Vectors}

To generate pcDNA3.1-TNC-1564-His encoding full-length human TNC-1564 isoform (GenBank XM_005251975) with a C-terminal His tag, a 4730-bp DNA fragment of pBS-HxB.S [23], including TNC-1564 cDNA was PCR-amplified using PrimeSTAR GXL DNA polymerase (TaKaRa, Shiga-ken, Japan), and a primer pair: 5'-GACGCTAGCCACCATGGGGGCCATGACTCA-3', which includes an NheI site (italicized) and nucleotides 309-329 of GenBank XM_005251975 containing a start codon (bold), and 5'-ATGGTACCTTAATGATGATGATGATGATGTGCCCGTTTGCGCCTGCCT-3', 
which includes a KpnI site (italicized), a stop codon (bold), His tag (underlined), and nucleotides 5004-4986 of Genbank XM_005251975. The PCR product was cleaved with NheI and KpnI and then ligated into the NheI and KpnI sites of pcDNA3.1 plasmid.

To generate pcDNA3.1-TNC-2201-His encoding full-length human TNC-2201 isoform (GenBank NM_002160) with a C-terminal His tag, a 3355-bp fragment corresponding to nucleotides 2706-6060 of GenBank NM_002160 sequence was isolated by cleavage of pBS-HxB.L [23] including TNC-2201 cDNA, with BstEII. Subsequently, the 3355-bp BstEII fragment was ligated into the 8686-bp BstEII fragment of pcDNA3.1-TNC-1564-His lacking a 1444-bp BstEII fragment corresponding to nucleotides 2706-4149 of GenBank XM_005251975 sequence. All the generated constructs were sequenced to confirm that their sequences were error-free.

\subsection{Purification of Recombinant Human TNC}

Subconfluent COS-1 cells were transfected with pcDNA3.1-TNC-2201-His or pcDNA3.1-TNC-1564-His using the calcium phosphate method for $16 \mathrm{~h}$, subsequently the cells were incubated with DMEM containing 5\% FBS for $24 \mathrm{~h}$. The cells were then washed with PBS three times and incubated with serum-free DMEM for $48 \mathrm{~h}$. Recombinant human TNC-2201 or TNC-1564 with C-terminal His tags were purified from the serum-free conditioned medium using $\mathrm{Ni}^{2+}$-NTA column chromatography (QIAGEN), following the manufacturer's recommendations. The eluted recombinant TNC-2201 or TNC-1564 polypeptides were dialyzed against PBS and stored as frozen aliquots at $-80{ }^{\circ} \mathrm{C}$.

\subsection{Construction of $p$ GEM-TGF- $\beta 1,2$, and 3 Vectors}

To generate $\mathrm{pGEM}$-TGF- $\beta 1,2$, and 3 vectors for use as positive controls in RT-PCR, 161-bp TGF- $\beta 1$, 162 -bp TGF- $\beta 2$, and 134-bp TGF- $\beta 3$ cDNA fragments were PCR-amplified using the primer pairs for RT-PCR (Supplementary Table S1, Taq DNA polymerase, and foreskin fibroblast cDNA as template. The cDNA fragments were then ligated into pGEM-T vector (Promega).

\subsection{Treatment of Fibroblasts with TNC or TGF- $\beta 1$ in the Presence or Absence of Signaling Blockers}

To analyze the expression levels of target genes, subconfluent foreskin fibroblasts were incubated in media containing 10\% FBS for $12 \mathrm{~h}$. The medium was replaced with fresh serum-free media containing $0.1 \%$ bovine serum albumin (BSA) with purified TNC $(2 \mu \mathrm{g} / \mathrm{mL})$ or TGF- $\beta 1(3 \mathrm{ng} / \mathrm{mL})$, and the cells were incubated for $12 \mathrm{~h}$ for mRNA analysis or for $24 \mathrm{~h}$ for protein analysis.

To analyze the phosphorylation of the signaling proteins, subconfluent foreskin fibroblasts were cultured in serum-free media for $10 \mathrm{~h}$. The medium was replaced with fresh serum-free media containing $0.1 \%$ BSA. After $2 \mathrm{~h}$, the cells were further incubated with either TNC ( $2 \mu \mathrm{g} / \mathrm{mL})$ or TGF- $\beta 1$ $(3 \mathrm{ng} / \mathrm{mL})$ for $90 \mathrm{~min}$ unless specified. In experiments involving signaling blockers, $10 \mu \mathrm{M}$ SB431542, $100 \mu \mathrm{g} / \mathrm{mL}$ RGD peptide, $2 \mu \mathrm{M}$ TC-I15, $10 \mu \mathrm{g} / \mathrm{mL}$ cycloheximide, or $3 \mu \mathrm{g} / \mathrm{mL}$ TGF- $\beta$ neutralizing antibody, were added $10 \mathrm{~min}$ prior to the treatment of the cells with TNC or TGF- $\beta 1$.

\subsection{Synthesis of Type I Collagen in Fibroblasts Grown in 3D Culture}

3D culture and immunofluorescence staining of fibroblasts were performed as previously described with minor modifications [53]. For 3D culture of fibroblasts, foreskin fibroblasts $\left(8 \times 10^{5}\right.$ cells $\left./ \mathrm{mL}\right)$ were trypsinized and resuspended in $2.8 \mathrm{mg} / \mathrm{mL}$ collagen I solution $(4 \mathrm{mg} / \mathrm{mL}$ rat tail Corning ${ }^{\circledR}$ collagen I:10× DMEM:10× reconstitution buffer $\left[260 \mathrm{mM} \mathrm{NaHCO}_{3}, 200 \mathrm{mM}\right.$ HEPES, and $50 \mathrm{mM} \mathrm{NaOH}]: 2 \mu \mathrm{g} / \mathrm{mL}$ TNC $=7: 1: 1: 1)$. The mixture $(0.15 \mathrm{~mL})$ was loaded onto a glass-bottom (35 mm $\times 10 \mathrm{~mm}$, hole $13 \Phi)$ dish (SPL Life Sciences, Pocheon, Korea). After allowing the solution to gel for $1 \mathrm{~h}$ at $37^{\circ} \mathrm{C}, 2 \mathrm{~mL}$ of phenol red-free DMEM (Hyclone, South Logan, UT, USA) was added, and the collagen-embedded cells were incubated for $24 \mathrm{~h}$ at $37^{\circ} \mathrm{C}$ with $5 \% \mathrm{CO}_{2}$ and $95 \%$ air. For nuclear staining, the cells were incubated with Hoechst $33258(2 \mu \mathrm{g} / \mathrm{mL})$ for $30 \mathrm{~min}$. After incubation, the cells were fixed in $3.7 \%$ paraformaldehyde for $30 \mathrm{~min}$, permeabilized with $0.2 \%$ Triton-X 100 for $30 \mathrm{~min}$, 
blocked with 3\% BSA for $30 \mathrm{~min}$, and immunostained with mouse anti-pro-COL1A1 antibody (1:50) overnight at $4{ }^{\circ} \mathrm{C}$. Samples were washed with PBS and incubated with Rhodamine Red-X-conjugated goat anti-mouse $\operatorname{IgG}(\mathrm{H}+\mathrm{L})$ antibody $(1 \mathrm{unit} / \mathrm{mL})$. Images were obtained using a confocal microscope (LSM880; Zeiss, Oberkochen, Germany) with a 20x objective lens and Zen software version 2.3 (Zeiss).

\subsection{Statistical Analysis}

All data are expressed as the mean \pm standard deviation (SD) of at least three independent experiments. Statistical significance was analyzed by Student's $t$-test, and $p<0.05$ was considered statistically significant.

\section{Conclusions}

In this study, we have shown that TNC is downregulated in aged skin tissues of mice and humans compared to young tissues. Expression of two major TNC isoforms, TNC-L and TNC-S, was observed in primary dermal fibroblasts. Recombinant TNC polypeptides, corresponding to TNC-L and TNC-S, increased the expression of type I collagen and decreased the expression of MMP-1, without discrepancy. A recombinant TNC polypeptide, corresponding to TNC-L, induced phosphorylation of SMAD2 and SMAD3 in fibroblasts. In addition, TNC induced transcription of TGF- $\beta 1 \mathrm{mRNA}$ and activated the TGF- $\beta$ signaling pathway, whereby the expression of type I collagen in fibroblasts was upregulated. Moreover, TNC promoted biosynthesis of type I collagen in the 3D culture system. Based on our findings, we propose that TNC expression in the skin plays a complementary role in the loss of ECM integrity that occurs in the intrinsic aging process.

Supplementary Materials: Supplementary Materials can be found at http:/www.mdpi.com/1422-0067/21/22/ 8693/s1. There were one Table S1 containing primer sequences used for RT-PCR, and one Figure S1 containing results of dermal thickness and collagen intensity in skin tissues of Tnc knockout and wild-type mice in Supplementary Materials.

Author Contributions: Conceptualization, Y.E.C. and S.-T.L.; methodology, Y.E.C., M.J.S. and M.H.; validation, Y.E.C. and S.-T.L.; investigation, Y.E.C., M.J.S., M.H., K.I.-Y., D.H.L., J.H.C. and S.-T.L.; resources, Y.E.C., M.J.S. and M.H.; data curation, Y.E.C. and S.-T.L.; writing-original draft preparation, Y.E.C. and S.-T.L.; writing - review and editing, K.I.-Y., D.H.L., J.H.C. and S.-T.L.; visualization, Y.E.C. and S.-T.L.; supervision, K.I.-Y., D.H.L., J.H.C. and S.-T.L.; project administration, S.-T.L.; funding acquisition, S.-T.L. All authors have read and agreed to the published version of the manuscript.

Funding: This research was funded by National Research Foundation of Korea (2019R111A2A01061685 and 2020R1A2C200655611 to S.-T.L.).

Acknowledgments: Y.E.C. was a fellowship awardee by the Brain Korea 21 plus program.

Conflicts of Interest: The authors declare no conflict of interest.

\section{Abbreviations}

$3 \mathrm{D}$

DAPI

DMEM

$\mathrm{ECM}$

EGF

MMP

IF

IHC

$\mathrm{KO}$

R-SMAD

RT-PCR

TGF- $\beta$

TNC

WT
Three-dimensional

4',6-diamidino-2-phenylindole

Dulbecco's modified Eagle's medium

Extracellular matrix

Epidermal growth factor

Matrix metalloproteinase

Immunofluorescence

Immunohistochemistry

Knockout

Receptor-regulated SMAD

Reverse transcription-polymerase chain reaction

Transforming growth factor- $\beta$

Tenascin C

Wild-type 


\section{References}

1. Midwood, K.S.; Chiquet, M.; Tucker, R.P.; Orend, G. Tenascin-C at a glance. J. Cell Sci. 2016, 129, 4321-4327. [CrossRef] [PubMed]

2. Berndt, A.; Richter, P.; Kosmehl, H.; Franz, M. Tenascin-C and carcinoma cell invasion in oral and urinary bladder cancer. Cell Adhes. Migr. 2015, 9, 105-111. [CrossRef] [PubMed]

3. Niebroj-Dobosz, I. Tenascin-C in human cardiac pathology. Clin. Chim. Acta 2012, 413, $1516-1518$. [CrossRef] [PubMed]

4. Brellier, F.; Tucker, R.P.; Chiquet-Ehrismann, R. Tenascins and their implications in diseases and tissue mechanics. Scand. J. Med. Sci. Sports 2009, 19, 511-519. [CrossRef] [PubMed]

5. Yeo, S.Y.; Lee, K.W.; Shin, D.; An, S.; Cho, K.H.; Kim, S.H. A positive feedback loop bi-stably activates fibroblasts. Nat. Commun. 2018, 9, 3016. [CrossRef]

6. Imanaka-Yoshida, K.; Tawara, I.; Yoshida, T. Tenascin-C in cardiac disease: A sophisticated controller of inflammation, repair, and fibrosis. Am. J. Physiol. Cell Physiol. 2020, 319, C781-C796. [CrossRef]

7. Murphy-Ullrich, J.E.; Sage, E.H. Revisiting the matricellular concept. Matrix Biol. 2014, 37, 1-14. [CrossRef]

8. Swindle, C.S.; Tran, K.T.; Johnson, T.D.; Banerjee, P.; Mayes, A.M.; Griffith, L.; Wells, A. Epidermal growth factor (EGF)-like repeats of human tenascin-C as ligands for EGF receptor. J. Cell Biol. 2001, 154, 459-468. [CrossRef]

9. Yoshida, T.; Akatsuka, T.; Imanaka-Yoshida, K. Tenascin-C and integrins in cancer. Cell Adhes. Migr. 2015, 9, 96-104. [CrossRef]

10. Tucker, R.P.; Chiquet-Ehrismann, R. Tenascin-C: Its functions as an integrin ligand. Int. J. Biochem. Cell Biol. 2015, 65, 165-168. [CrossRef]

11. Midwood, K.S.; Hussenet, T.; Langlois, B.; Orend, G. Advances in tenascin-C biology. Cell. Mol. Life Sci. 2011, 68, 3175-3199. [CrossRef] [PubMed]

12. Paron, I.; Berchtold, S.; Voros, J.; Shamarla, M.; Erkan, M.; Hofler, H.; Esposito, I. Tenascin-C enhances pancreatic cancer cell growth and motility and affects cell adhesion through activation of the integrin pathway. PLoS ONE 2011, 6, e21684. [CrossRef] [PubMed]

13. Katoh, D.; Nagaharu, K.; Shimojo, N.; Hanamura, N.; Yamashita, M.; Kozuka, Y.; Imanaka-Yoshida, K.; Yoshida, T. Binding of alphavbeta1 and alphavbeta6 integrins to tenascin-C induces epithelial-mesenchymal transition-like change of breast cancer cells. Oncogenesis 2013, 2, e65. [CrossRef] [PubMed]

14. Lange, K.; Kammerer, M.; Hegi, M.E.; Grotegut, S.; Dittmann, A.; Huang, W.; Fluri, E.; Yip, G.W.; Gotte, M.; Ruiz, C.; et al. Endothelin receptor type B counteracts tenascin-C-induced endothelin receptor type A-dependent focal adhesion and actin stress fiber disorganization. Cancer Res. 2007, 67, 6163-6173. [CrossRef]

15. Katoh, D.; Kozuka, Y.; Noro, A.; Ogawa, T.; Imanaka-Yoshida, K.; Yoshida, T. Tenascin-C induces phenotypic changes in fibroblasts to myofibroblasts with high contractility through the integrin alphavbeta1/transforming growth factor beta/SMAD signaling axis in human breast cancer. Am. J. Pathol. 2020, 190, 2123-2135. [CrossRef]

16. Bhattacharyya, S.; Wang, W.; Morales-Nebreda, L.; Feng, G.; Wu, M.; Zhou, X.; Lafyatis, R.; Lee, J.; Hinchcliff, M.; Feghali-Bostwick, C.; et al. Tenascin-C drives persistence of organ fibrosis. Nat. Commun. 2016, 7, 11703. [CrossRef]

17. Ma, J.C.; Huang, X.; Shen, Y.W.; Zheng, C.; Su, Q.H.; Xu, J.K.; Zhao, J. Tenascin-C promotes migration of hepatic stellate cells and production of type I collagen. Biosci. Biotechnol. Biochem. 2016, 80, 1470-1477. [CrossRef]

18. Kasprzycka, M.; Hammarstrom, C.; Haraldsen, G. Tenascins in fibrotic disorders-from bench to bedside. Cell Adhes. Migr. 2015, 9, 83-89. [CrossRef]

19. Quan, T.; Shao, Y.; He, T.; Voorhees, J.J.; Fisher, G.J. Reduced expression of connective tissue growth factor (CTGF/CCN2) mediates collagen loss in chronologically aged human skin. J. Investig. Dermatol. 2010, 130, 415-424. [CrossRef]

20. El-Karef, A.; Yoshida, T.; Gabazza, E.C.; Nishioka, T.; Inada, H.; Sakakura, T.; Imanaka-Yoshida, K. Deficiency of tenascin-C attenuates liver fibrosis in immune-mediated chronic hepatitis in mice. J. Pathol. 2007, 211, 86-94. [CrossRef]

21. Carey, W.A.; Taylor, G.D.; Dean, W.B.; Bristow, J.D. Tenascin-C deficiency attenuates TGF-ss-mediated fibrosis following murine lung injury. Am. J. Physiol. Lung Cell. Mol. Physiol. 2010, 299, L785-L793. [CrossRef] [PubMed] 
22. Jinnin, M.; Ihn, H.; Asano, Y.; Yamane, K.; Trojanowska, M.; Tamaki, K. Upregulation of tenascin-C expression by IL-13 in human dermal fibroblasts via the phosphoinositide 3-kinase/Akt and the protein kinase C signaling pathways. J. Investig. Dermatol. 2006, 126, 551-560. [CrossRef] [PubMed]

23. Aukhil, I.; Joshi, P.; Yan, Y.; Erickson, H.P. Cell- and heparin-binding domains of the hexabrachion arm identified by tenascin expression proteins. J. Biol. Chem. 1993, 268, 2542-2553. [PubMed]

24. Khan, Z.; Marshall, J.F. The role of integrins in TGFbeta activation in the tumour stroma. Cell Tissue Res. 2016, 365, 657-673. [CrossRef]

25. Ogawa, K.; Ito, M.; Takeuchi, K.; Nakada, A.; Heishi, M.; Suto, H.; Mitsuishi, K.; Sugita, Y.; Ogawa, H.; $\mathrm{Ra}, \mathrm{C}$. Tenascin-C is upregulated in the skin lesions of patients with atopic dermatitis. J. Dermatol. Sci. 2005, 40, 35-41. [CrossRef]

26. Latijnhouwers, M.A.; de Jongh, G.J.; Bergers, M.; de Rooij, M.J.; Schalkwijk, J. Expression of tenascin-C splice variants by human skin cells. Arch. Dermatol. Res. 2000, 292, 446-454. [CrossRef]

27. Chung, J.H.; Seo, J.Y.; Choi, H.R.; Lee, M.K.; Youn, C.S.; Rhie, G.; Cho, K.H.; Kim, K.H.; Park, K.C.; Eun, H.C. Modulation of skin collagen metabolism in aged and photoaged human skin in vivo. J. Investig. Dermatol. 2001, 117, 1218-1224. [CrossRef]

28. Latijnhouwers, M.; Bergers, M.; Ponec, M.; Dijkman, H.; Andriessen, M.; Schalkwijk, J. Human epidermal keratinocytes are a source of tenascin-C during wound healing. J. Investig. Dermatol. 1997, 108, 776-783. [CrossRef]

29. Chung, C.Y.; Murphy-Ullrich, J.E.; Erickson, H.P. Mitogenesis, cell migration, and loss of focal adhesions induced by tenascin-C interacting with its cell surface receptor, annexin II. Mol. Biol. Cell 1996, 7, 883-892. [CrossRef]

30. Orend, G.; Huang, W.; Olayioye, M.A.; Hynes, N.E.; Chiquet-Ehrismann, R. Tenascin-C blocks cell-cycle progression of anchorage-dependent fibroblasts on fibronectin through inhibition of syndecan-4. Oncogene 2003, 22, 3917-3926. [CrossRef]

31. Chiquet-Ehrismann, R.; Matsuoka, Y.; Hofer, U.; Spring, J.; Bernasconi, C.; Chiquet, M. Tenascin variants: Differential binding to fibronectin and distinct distribution in cell cultures and tissues. Cell Regul. 1991, 2, 927-938. [CrossRef] [PubMed]

32. Ghert, M.A.; Qi, W.N.; Erickson, H.P.; Block, J.A.; Scully, S.P. Tenascin-C splice variant adhesive/anti-adhesive effects on chondrosarcoma cell attachment to fibronectin. Cell Struct. Funct. 2001, 26, 179-187. [CrossRef] [PubMed]

33. Prieto, A.L.; Andersson-Fisone, C.; Crossin, K.L. Characterization of multiple adhesive and counteradhesive domains in the extracellular matrix protein cytotactin. J. Cell Biol. 1992, 119, 663-678. [CrossRef] [PubMed]

34. Saga, Y.; Yagi, T.; Ikawa, Y.; Sakakura, T.; Aizawa, S. Mice develop normally without tenascin. Genes Dev. 1992, 6, 1821-1831. [CrossRef]

35. Forsberg, E.; Hirsch, E.; Frohlich, L.; Meyer, M.; Ekblom, P.; Aszodi, A.; Werner, S.; Fassler, R. Skin wounds and severed nerves heal normally in mice lacking tenascin-C. Proc. Natl. Acad. Sci. USA 1996, 93, 6594-6599. [CrossRef]

36. Song, L.; Wang, L.; Li, F.; Yukht, A.; Qin, M.; Ruther, H.; Yang, M.; Chaux, A.; Shah, P.K.; Sharifi, B.G. Bone marrow-derived tenascin-C attenuates cardiac hypertrophy by controlling inflammation. J. Am. Coll. Cardiol. 2017, 70, 1601-1615. [CrossRef]

37. Xie, K.; Liu, Y.; Hao, W.; Walter, S.; Penke, B.; Hartmann, T.; Schachner, M.; Fassbender, K. Tenascin-C deficiency ameliorates Alzheimer's disease-related pathology in mice. Neurobiol. Aging 2013, 34, 2389-2398. [CrossRef]

38. Shimojo, N.; Hashizume, R.; Kanayama, K.; Hara, M.; Suzuki, Y.; Nishioka, T.; Hiroe, M.; Yoshida, T.; Imanaka-Yoshida, $\mathrm{K}$. Tenascin-C may accelerate cardiac fibrosis by activating macrophages via the integrin alphaVbeta3/nuclear factor-kappaB/interleukin-6 axis. Hypertension 2015, 66, 757-766. [CrossRef]

39. Munger, J.S.; Huang, X.; Kawakatsu, H.; Griffiths, M.J.; Dalton, S.L.; Wu, J.; Pittet, J.F.; Kaminski, N.; Garat, C.; Matthay, M.A.; et al. The integrin alpha v beta 6 binds and activates latent TGF beta 1: A mechanism for regulating pulmonary inflammation and fibrosis. Cell 1999, 96, 319-328. [CrossRef]

40. Hayashida, T.; Wu, M.H.; Pierce, A.; Poncelet, A.C.; Varga, J.; Schnaper, H.W. MAP-kinase activity necessary for TGFbeta1-stimulated mesangial cell type I collagen expression requires adhesion-dependent phosphorylation of FAK tyrosine 397. J. Cell Sci. 2007, 120, 4230-4240. [CrossRef] 
41. White, L.A.; Mitchell, T.I.; Brinckerhoff, C.E. Transforming growth factor beta inhibitory element in the rabbit matrix metalloproteinase-1 (collagenase-1) gene functions as a repressor of constitutive transcription. Biochim. Biophys. Acta 2000, 1490, 259-268. [CrossRef]

42. Galoian, K.A.; Garamszegi, N.; Garamszegi, S.P.; Scully, S.P. Molecular mechanism of tenascin-C action on matrix metalloproteinase-1 invasive potential. Exp. Biol. Med. 2007, 232, 515-522.

43. Rogers, N.K.; Clements, D.; Dongre, A.; Harrison, T.W.; Shaw, D.; Johnson, S.R. Extra-cellular matrix proteins induce matrix metalloproteinase-1 (MMP-1) activity and increase airway smooth muscle contraction in asthma. PLoS ONE 2014, 9, e90565. [CrossRef] [PubMed]

44. Tobin, D.J. Introduction to skin aging. J. Tissue Viability 2017, 26, 37-46. [CrossRef] [PubMed]

45. Slominski, A.T.; Zmijewski, M.A.; Skobowiat, C.; Zbytek, B.; Slominski, R.M.; Steketee, J.D. Sensing the environment: Regulation of local and global homeostasis by the skin's neuroendocrine system. Adv. Anat. Embryol. Cell Biol. 2012, 212, 1-115.

46. Bocheva, G.; Slominski, R.M.; Slominski, A.T. Neuroendocrine aspects of skin aging. Int. J. Mol. Sci. 2019, 20, 2798. [CrossRef]

47. Sumioka, T.; Kitano, A.; Flanders, K.C.; Okada, Y.; Yamanaka, O.; Fujita, N.; Iwanishi, H.; Kao, W.W.; Saika, S. Impaired cornea wound healing in a tenascin C-deficient mouse model. Lab. Investig. 2013, 93, 207-217. [CrossRef]

48. Brellier, F.; Martina, E.; Chiquet, M.; Ferralli, J.; van der Heyden, M.; Orend, G.; Schittny, J.C.; Chiquet-Ehrismann, R.; Tucker, R.P. The adhesion modulating properties of tenascin-W. Int. J. Biol. Sci. 2012, 8, 187-194. [CrossRef]

49. Kim, E.J.; Kim, Y.K.; Kim, M.K.; Kim, S.; Kim, J.Y.; Lee, D.H.; Chung, J.H. UV-induced inhibition of adipokine production in subcutaneous fat aggravates dermal matrix degradation in human skin. Sci. Rep. 2016, 6, 25616. [CrossRef]

50. Shin, J.E.; Oh, J.H.; Kim, Y.K.; Jung, J.Y.; Chung, J.H. Transcriptional regulation of proteoglycans and glycosaminoglycan chain-synthesizing glycosyltransferases by UV irradiation in cultured human dermal fibroblasts. J. Korean Med. Sci. 2011, 26, 417-424. [CrossRef]

51. Shin, W.S.; Park, M.K.; Lee, Y.H.; Kim, K.W.; Lee, H.; Lee, S.-T. The catalytically defective receptor protein tyrosine kinase EphA10 promotes tumorigenesis in pancreatic cancer cells. Cancer Sci. 2020, 111, 3292-3302. [CrossRef] [PubMed]

52. Shin, W.S.; Lee, H.W.; Lee, S.-T. Catalytically inactive receptor tyrosine kinase PTK7 activates FGFR1 independent of FGF. FASEB J. 2019, 33, 12960-12971. [CrossRef] [PubMed]

53. Lee, Y.H.; Seo, E.K.; Lee, S.-T. Skullcapflavone II inhibits degradation of type I collagen by suppressing MMP-1 transcription in human skin fibroblasts. Int. J. Mol. Sci. 2019, 20, 2734. [CrossRef] [PubMed]

Publisher's Note: MDPI stays neutral with regard to jurisdictional claims in published maps and institutional affiliations.

(C) 2020 by the authors. Licensee MDPI, Basel, Switzerland. This article is an open access article distributed under the terms and conditions of the Creative Commons Attribution (CC BY) license (http://creativecommons.org/licenses/by/4.0/). 